\title{
A PRELIMINARY STUDY OF THE COLEMANITE-RICH TUFF LAYER FROM THE SOURIDES AREA, KARLOVASSI BASIN, SAMOS ISLAND, HELLAS
}

\author{
Kantiranis N. ${ }^{1}$, Filippidis A. ${ }^{1}$, Stamatakis M. ${ }^{2}$, Tzamos E. ${ }^{1}$, and Drakoulis A. ${ }^{1}$ \\ ${ }^{1}$ Aristotle University of Thessaloniki, Faculty of Sciences, School of Geology, Department of \\ Mineralogy-Petrology-Economic Geology,kantira@geo.auth.gr,anestis@geo.auth.gr, \\ tzamos@geo.auth.gr,alexdr@geo.auth.gr, \\ ${ }^{2}$ National and Kapodistrian University of Athens, Faculty of Geology and Geoenvironment, \\ Department of Economic Geology and Geochemistry, stamatakis@geol.uoa.gr
}

\begin{abstract}
Representative $3 \mathrm{~kg}$ sample of a colemanite-bearing tuffaceous layer from Sourides village of Samos Island have been investigated for its mineralogical and chemical composition using Light Microscopy, X-Ray Powder Diffraction and Atomic Adsorption Spectroscopy methods. The studied sample contains $68 \mathrm{wt} \%$ colemanite, consisting of $31.1 \mathrm{wt} . \% \mathrm{~B}_{2} \mathrm{O}_{3}$ and $28.4 \mathrm{wt} . \% \mathrm{CaO}$. The mineralogical and chemical composition of the sample, after calcination could produce a concentrate containing 43-44 wt.\% $\mathrm{B}_{2} \mathrm{O}_{3}$, fulfill at least one of the commercial specifications for the calcined colemanite concentrates.
\end{abstract}

Key words: Borates, calcite, Greece.

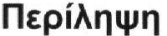

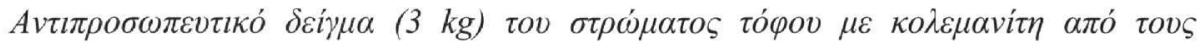

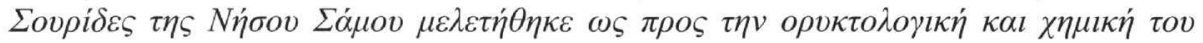

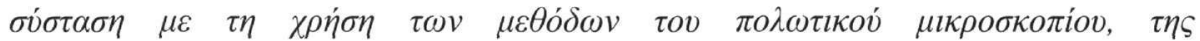

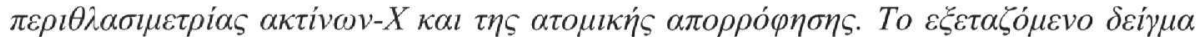
a

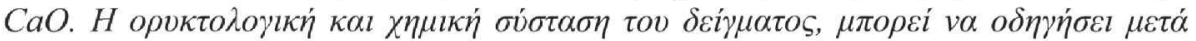

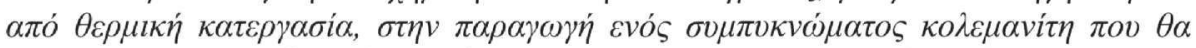

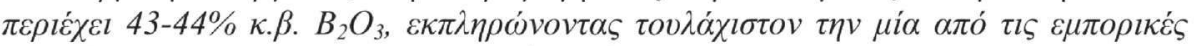
$\alpha \pi \alpha i \tau \dot{\sigma \varepsilon l \varsigma ~ \gamma l \alpha ~ \tau o ~ \sigma v \mu \pi v ́ \kappa v \omega \mu \alpha ~ \tau o v ~ \kappa o \lambda \varepsilon \mu \alpha v i т \eta . ~}$

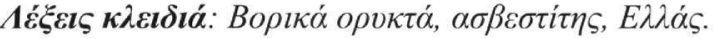

\section{Introduction}

Borates is a group of minerals that contain $\mathrm{B}_{2} \mathrm{O}_{3}$. Industry defined borates as any compound that contains or supplies boric oxide. A large number of minerals contain boric oxide, but the three that are the most important from a worldwide commercial standpoint are of the $\mathrm{Na}-\mathrm{Ca} / \mathrm{Na}$ and $\mathrm{Ca}$ borates, such as borax, ulexite and colemanite respectively. The world boron minerals production is approximately 4.4 million metric tones of $\mathrm{B}_{2} \mathrm{O}_{3}$, these minerals are produced mainly in the Turkey and U.S.A., followed by Argentina, Russia, Chile and China (Lyday 1992, Kistler and 
Helvaci 1994, Bonel and Chapman 2005). Borate minerals may be divided into three broad groups according to their origin and geological environments (Ozal 1977, Helvaci 1984, Kistler and Helvaci 1994): a) skarn minerals related to intrusives, mainly silicates and iron oxides; b) magnesium oxides related to marine sediments; and c) hydrated sodium and calcium borates related to continental sediments and volcanic activity. In groups (a) and (b), the major ones being datolite and szaibelyite, while in group (c) are borax, kernite, colemanite and ulexite. Colemanite is the preferred calcium-bearing borate, with low solubility in water, although it dissolves readily in acid. The principal uses of borates include glass-fiber insulation, textile grade fiber, soaps, detergents, borosilicate glass, fire retardants, enamels, glazes and agriculture. Minor markets include boron fiber-reinforced plastics, wood preservatives, alloys and amorphous metals, insecticides, pharmaceuticals, medical, cosmetics, anti-corrosion compounds, adhesives, abrasives, nuclear shielding, super magnets, and micro-nutrition agents (Kistler and Helvaci 1994, Harben 2002). The quality demands of borate ore purchased and prised based on the $\mathrm{B}_{2} \mathrm{O}_{3}$ content. Calcined colemanite concentrate has approximately $42 \% \mathrm{~B}_{2} \mathrm{O}_{3}$ with As (penalty element) ranging from 30-2,000 ppm, while washed and ground ulexite $38 \% \mathrm{~B}_{2} \mathrm{O}_{3}$ and technical grade boric acid $56.3 \% \mathrm{~B}_{2} \mathrm{O}_{3}$. Glass requires a low content of colouring metals such as $\mathrm{Fe}, \mathrm{Co}, \mathrm{Ni}, \mathrm{Cu}$ and $\mathrm{Ti}$. Ferroboron typically contain $18 \% \mathrm{~B}, 0.5 \% \mathrm{C}, 0.5 \% \mathrm{Si}, 0.2 \% \mathrm{Al}, 0.03 \% \mathrm{P}$ and $0.01 \% \mathrm{~S}$ in lump form with a minimum size of 0.2 inch.

The present paper is an exploratory study for the colemanite-containing tuffaceous layer occurred near the Sourides village, south of Karlovassi town in Samos Island. It is focused on the semiquantitative mineralogical and chemical composition of a $3 \mathrm{~kg}$ sample in order to define the potential uses of the colemanite-containing tuffaceous layers of Samos.

\section{Geological setting}

The pre-Neogene basement of the Karlovassi lake basin consists of metamorphic rocks, marbles on the western margin, and schists interbedded with marbles on the eastern margin of the lake (Fig. 1). Miocene acid lavas were recognized on the eastern margin of the basin and small bodies of basic to intermediate lavas in both the east and west margins (Theodoropoulos 1979). Within the period from Tortonian through Messinian the Karlovassi basin was filled with a basal conglomerate, limestone, ash-fall tephra, and other tuffaceous rocks, marlstone, claystone, and finally a siliceous limestone. After uplift, which occurred during the latest stage of the Miocene, terrestrial sediments and tuffs of uppermost Miocene age and Pliocene fresh-water marlstone were unconformably deposited over the oldest rocks (Theodoropoulos 1979, Stamatakis and Economou 1991). The volcaniclastic material deposited in the Karlovassi basin is represented by very fine grained particles, identified as ash-fall tephra and tuffite (Stamatakis 1989a) which are accompanied by much less abundant coarser tuffaceous rocks. The thickest accumulation of the tuffaceous rocks is found in the central part of the lake, where it is succeeded stratigraphically by a clay-rich succession. The initial glassy volcanic ash is now represented by authigenic smectite, clinoptilolite, analcime and potassium feldspar (Stamatakis 1986, 1989a, 1989b).

Stamatakis and Economou (1991) have described the occurrence, the genesis and mineral chemistry of the borate minerals in the Karlovassi Basin of Samos Island. They found borate minerals in the zone of intermixed tuffaceous and clay-rich members of the Late Miocene rocks. The evaporitic minerals gypsum, colemanite, ulexite and celestite occur with the form of layers, nodules, lenses or fissure fillings in close association with claystones within the alternating sequence.

\section{Materials and methods}

Representative $3 \mathrm{~kg}$ sample of colemanite-containing tuffaceous layer was collected from the Sourides area, of the Karlovassi basin of Samos Island (Fig. 1). The sample was ground, homogenized and separated into two equal portions. The first portion was ground further and used 
for chemical analysis while the second portion was used for mineralogical analysis. The mineralogical composition of the sample was studied in thin sections under light microscope, while powdered sample was used for the determination of the semi-quantitative mineralogical composition using the X-ray diffraction method. Both, chemical and mineralogical analyses were performed at the laboratories of the Department of Mineralogy-Petrology-Economic Geology of the Aristotle University.

X-ray Powder diffraction (XRPD) was performed using a Philips PW 1710 diffractometer with Nifiltered $\mathrm{CuK} \alpha$ radiation. The sample was scanned over the $3-63^{\circ} 2 \theta$ at a scanning speed of 1.2 $\% / \mathrm{min}$. Semi-quantitative estimates of the abundance of the mineral phases were derived from the XRPD data, using the intensity of certain reflections, the density and the mass absorption coefficient for $\mathrm{CuK} \alpha$ radiation for the minerals present. Then results were corrected using standard mixtures of minerals (external standards) scanned under the same conditions.

Chemical analysis of the studied sample was carried out using atomic absorption spectrometry (AAS) on a Perkin-Elmer 5000 spectrometer equipped with graphite furnace.

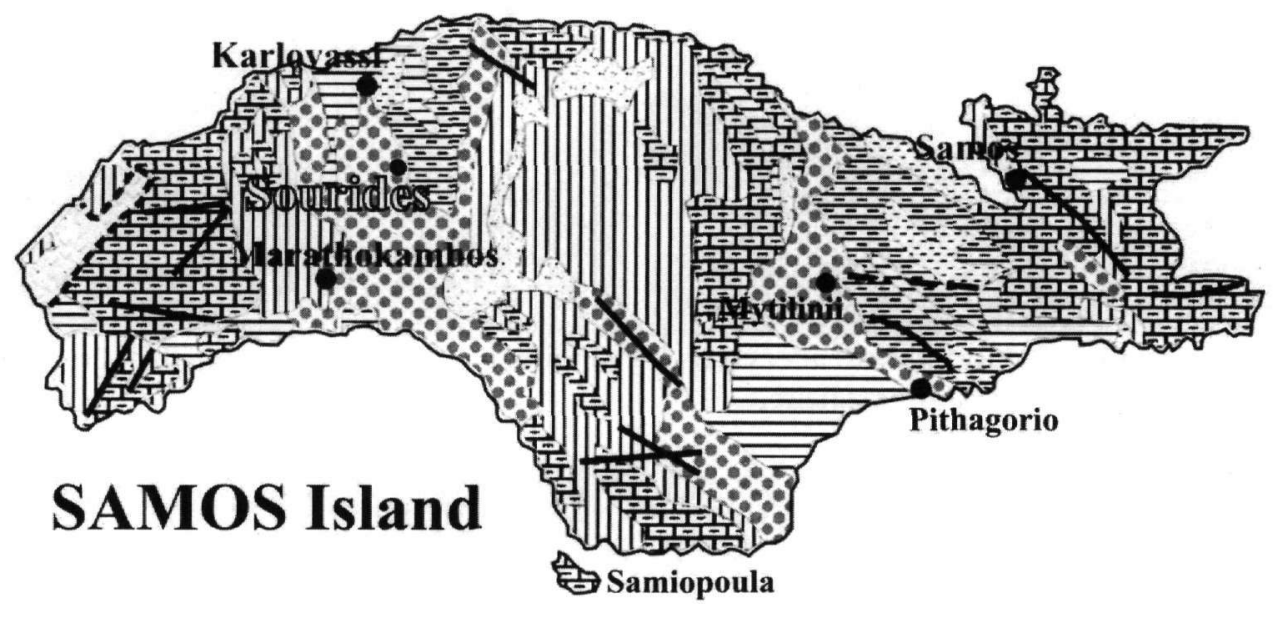

LEGEND
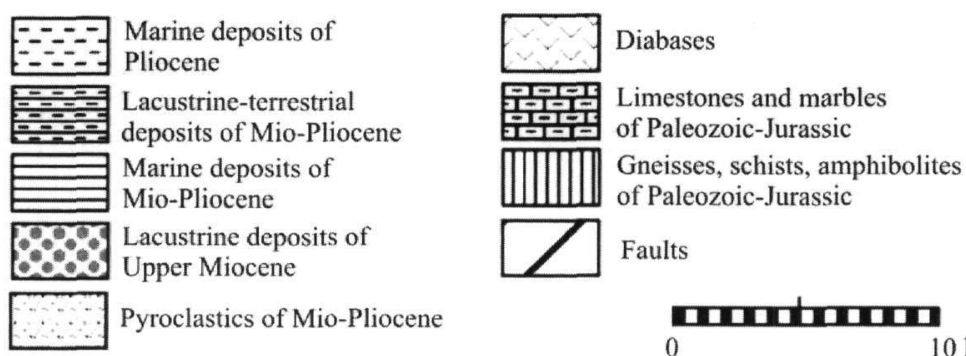

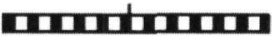

$0 \quad 10 \mathrm{~km}$

Figure 1 - Simplified geological map of Samos Island (Kantiranis et al. 2004) and sample location

\section{Results and Discussion}

Microscopic examination of the sample showed the presence of colemanite as major phase, calcite as minor phase and traces of quartz and micas. Colemanite (Figs 2-5) occurs as subhedral to anhedral crystals, with well-developed cleavage. Colemanite and calcite are directly related and it seems that colemanite converts to calcite (Figs 2, 3) and this secondary produced calcite converts to collemanite (Figs 4, 5). Calcitic earthy material usually with a spongy form, replaces the early 
formed borates of the Karlovassi basin near the surface (Stamatakis and Economou 1991). The presence of calcite as a weathering product developed on the surficial body of colemanite and the transformation of secondary calcite to colemanite during diagenesis is a quite common phenomenon in similar occurrences (Helvaci 1984, Alonso et al. 1988). The conversion of colemanite to calcite is caused by intense weathering involving subsurface moving waters and often the calcite shows pseudomorphism after colemanite (Helvaci 1984). The intense weathering of the colemanite-bearing bodies of the Karlovassi basin was favoured by the large-scale tectonic events which affect the late Miocene sedimentary rocks and resulted in the exposure of the evaporate-bearing rocks to surface conditions. This suggestion is supported by the abundant NWSE and NE-SW trending faults. The observed slumping southwest of the borate lens is evidence of tectonic disturbances during the time of sedimentation (Stamatakis and Economou 1991).

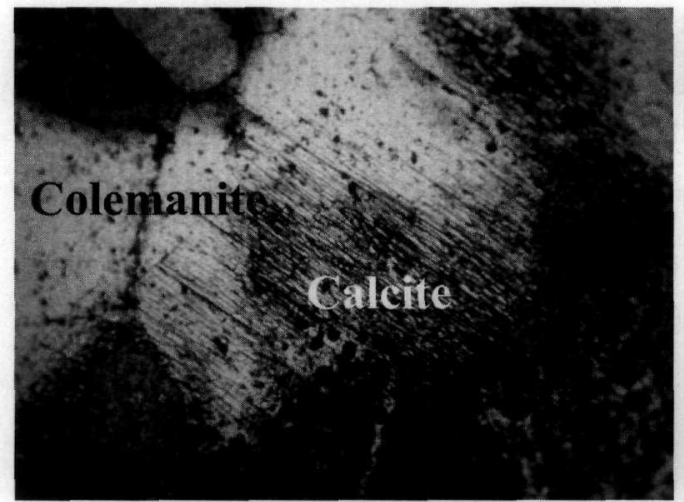

Figure 2 - Colemanite subhedral crystals showing conversion to calcite,

Nicols //, X4.33

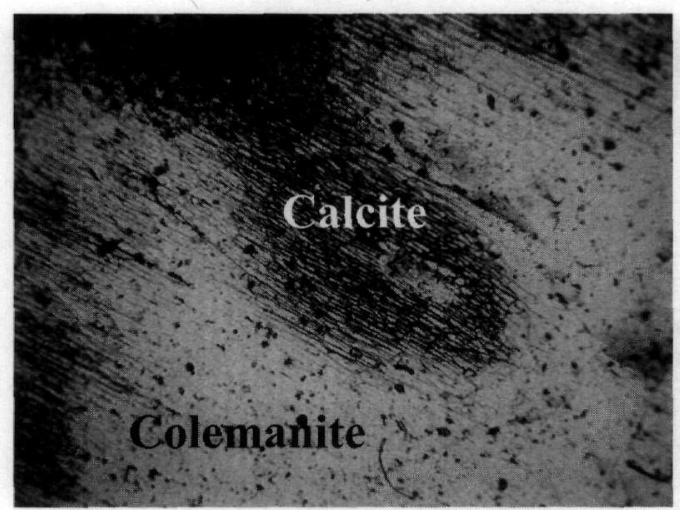

Figure 4 - Secondary calcite with welldeveloped cleavage converts to colemanite, Nicols //, X4.33

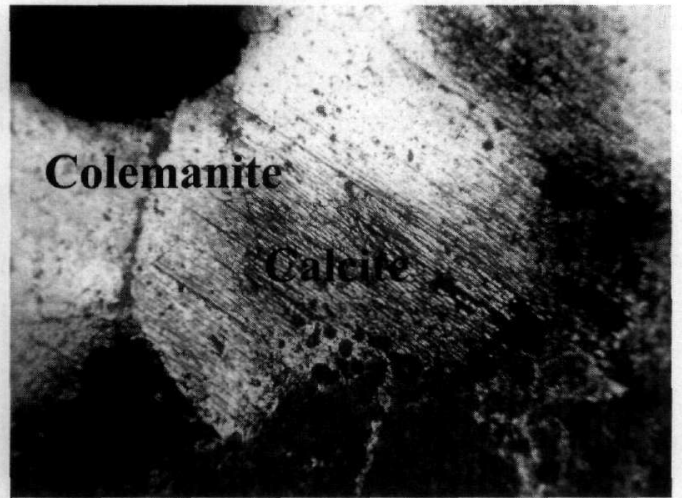

Figure 3 - Colemanite subhedral crystals showing conversion to calcite, Nicols + , X4.33

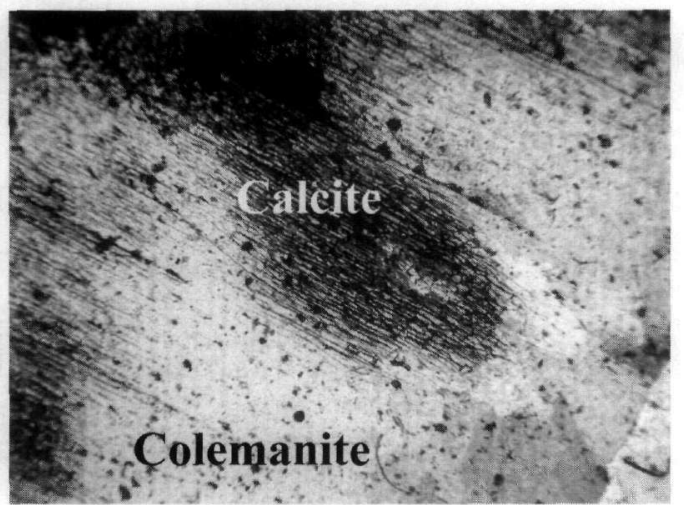

Figure 5 - Secondary calcite with welldeveloped cleavage converts to colemanite, Nicols + , X4.33

The semi-quantitative mineralogical composition and chemical analysis of the studied sample are presented in Table 1. Colemanite constitutes the $68 \mathrm{wt} . \%$ and the other minerals present are calcite (18 wt.\%), clay minerals (8 wt.\%), quartz (4 wt.\%) and micas (2 wt.\%). The main oxides found in the chemical analysis (Table 1$)$ of the sample are $\mathrm{B}_{2} \mathrm{O}_{3}(31,06 \mathrm{wt} . \%)$ and $\mathrm{CaO}(28.40 \mathrm{wt} . \%)$. In minor amounts, $\mathrm{MgO}$ (5.77 wt.\%) and $\mathrm{SiO}_{2}$ (4.13 wt.\%) were measured. The values of the chemical analysis are in good agreement with those of the semi-quantitative mineralogical composition.

Commercially, borate ore is purchased and priced according to the $\mathrm{B}_{2} \mathrm{O}_{3}$ content and for calcined colemanite concentrate approximately 42 wt. $\% \mathrm{~B}_{2} \mathrm{O}_{3}$, with As (penalty element) ranging from 30- 
$2000 \mathrm{ppm}$ (Harben 2002). According to the mineralogical and chemical composition (Table 1) the studied colemanite sample after calcination could reach a value of 43.9 wt. $\% \mathrm{~B}_{2} \mathrm{O}_{3}$.

Table 1 - Semi-quantitative mineralogical and chemical analysis of the studied sample

\begin{tabular}{|c|c|c|c|}
\hline \multicolumn{2}{|c|}{ Mineralogical composition (wt.\%) } & \multicolumn{2}{|c|}{ Chemical analysis (wt.\%) } \\
\hline \multirow[t]{3}{*}{ Colemanite } & \multirow[t]{3}{*}{68} & $\mathrm{SiO}_{2}$ & 4.13 \\
\hline & & $\mathrm{TiO}_{2}$ & 0.04 \\
\hline & & $\mathrm{Al}_{2} \mathrm{O}_{3}$ & 0.47 \\
\hline \multirow[t]{3}{*}{ Calcite } & \multirow[t]{3}{*}{18} & $\mathrm{Fe}_{2} \mathrm{O}_{3 \mathrm{t}}$ & 0.19 \\
\hline & & $\mathrm{B}_{2} \mathrm{O}_{3}$ & 31.06 \\
\hline & & $\mathrm{MnO}$ & 0.01 \\
\hline \multirow[t]{3}{*}{ Clay minerals } & \multirow[t]{3}{*}{8} & $\mathrm{MgO}$ & 5.77 \\
\hline & & $\mathrm{CaO}$ & 28.40 \\
\hline & & $\mathrm{SrO}$ & 0.39 \\
\hline \multirow[t]{3}{*}{ Quartz } & \multirow[t]{3}{*}{4} & $\mathrm{BaO}$ & bdl \\
\hline & & $\mathrm{Na}_{2} \mathrm{O}$ & 0.16 \\
\hline & & $\mathrm{K}_{2} \mathrm{O}$ & 0.13 \\
\hline \multirow[t]{2}{*}{ Micas } & \multirow[t]{2}{*}{2} & $\mathrm{P}_{2} \mathrm{O}_{5}$ & 0.01 \\
\hline & & L.O.I.* & 29.14 \\
\hline Total & 100 & Total & 99.90 \\
\hline
\end{tabular}

\section{Conclusions}

The representative $3 \mathrm{~kg}$ sample of the tuffaceous layer from Sourides village in Karlovassi basin of Samos Island contains $68 \mathrm{wt} . \%$ colemanite, $18 \mathrm{wt} . \%$ calcite, $8 \mathrm{wt} . \%$ clay minerals, $4 \mathrm{wt} . \%$ quartz and $2 \mathrm{wt} \%$ micas. Chemically the colemanite tuffaceous layer mainly consists of $31.1 \mathrm{wt} \% \mathrm{~B}_{2} \mathrm{O}_{3}$, 28,4 wt. $\% \mathrm{CaO}, 5.8$ wt. $\% \mathrm{MgO}$ and 4.1 wt. $\% \mathrm{SiO}_{2}$. The results of the chemical analysis are in good agreement with the mineralogical composition determined by XRPD.

Based on the mineralogical and chemical composition the raw colemanite-rich tuffaceous sample, after calcination could produce a concentrate with approximately $43-44$ wt. $\% \mathrm{~B}_{2} \mathrm{O}_{3}$, fulfilling at least one of the above mentioned specifications for the colemanite concentrate. Furthermore, it is expected the $\mathrm{B}_{2} \mathrm{O}_{3}$ content of the processed sample, during its possible industrial utilization to be increased.

It should be emphasized that more detailed study of the Sourides area involving sampling and determination of the mineralogy and chemistry, is under the way for the final conclusion of the economical and commercial value of the borate occurrences of Samos Island.

\section{References}

Alonso, R.N., and Helvaci, C., 1988. Mining and concentration of borates in Argentina, Proc. $2^{\text {nd }}$ Inter. Mineral Proc. Symp., Izmir, 301-305. 
Bonel, K.A., and Chapman, G.R., 2005. World metals \& Minerals Review 2005, Metal Bulletin, London, $312 \mathrm{pp}$.

Harben, W.P., 2002. The industrial minerals handybook, A guide to markets, specifications \& prices, $4^{\text {th }}$ Edn. Blackwood UK, Pensord, 409pp.

Helvaci, C., 1984. Occurrence of rare borate minerals Veatchite-A, Tunnelite, Terrugite and Cahnite in the Emet borate deposits, Mineralium Deposita, 19, 217-226.

Kantiranis, N., Stamatakis, M., Filippidis, A., and Squires, C., 2004. The uptake ability of the clinoptilolitic tuffs of Samos island, Greece, Bull. Geol. Soc. Greece, 36, 89-96.

Kistler, B., and Helvaci, C., 1994. Boron and Borates, In D.D. Carr, (ed.), Industrial Minerals and rocks, 171-186, Ann Arbor, Michigan, Braun-Brumfield, 1196pp.

Lyday, P.A., 1992. History of boron production and processing, Industrial minerals, December, 19-35.

Ozal, A.A., 1977. Plate tectonics and the process of volcanogenic-sedimentary formation of Boron, International Geology Review, 20/6, 692-698.

Stamatakis, G.M., 1986. Boron distribution in thermal springs, marine evaporites and Cenozoic sedimentary and volcanic rocks of Greece, $P h D$ Thesis, University of Athens, $465 \mathrm{pp}$.

Stamatakis, G.M., 1989a. Authigenic silicates and silica polymorphs in the Miocene salinealkaline deposits of the Karlovassi basin, Samos, Greece, Economic Geology, 84, 788-798.

Stamatakis, G.M., 1989b. A boron-bearing potassium feldspar in volcanic ash and tuffaceous rocks from Miocene lake deposits, Samos Island, Greece, American Mineralogist, 74, 230235 .

Stamatakis, G.M., and Economou, S.G., 1991. A colemanite and ulexite occurrence in a Late Miocene saline-alkaline lake of West Samos Island, Greece, Economic Geology, 86/1, 166172.

Theodoropoulos, D., 1979. Geological map of Greece. Sheet: Neon Karlovassi, scale 1:50.000. IGME, Athens. 